\title{
THE EFFECT OF LIQUIDITY, NET INTEREST MARGIN AND GOOD CORPORATE GOVERNANCE RISK ON SHARIA BANKING FINANCIAL PERFORMANCE
}

\author{
Toni Hidayat, \\ Abdul Malik, \\ Disna Anum Siregar, \\ Munawaroh $^{\mathrm{i}}$ \\ Universitas Muslim Nusantara Al Washliyah, \\ Indonesia
}

\begin{abstract}
:
This research is categorized as quantitative research. While the research design used in this research is correlation analysis, which is a type of research carried out with the aim of detecting the extent to which variations in a factor are correlated with one or more other factors based on the correlation coefficient. The research objective is to explain the effect and hypothesis testing by analyzing various data in the field. In the context of this research is to obtain facts from existing phenomena and to seek factual information about the improvement of Islamic banking financial performance. The population in this study were 11 Islamic banks in Indonesia with a 3-year observation period 2018-2020. The technique for determining the number of samples used was the saturated sample method in which the number of sample observations was 33 observation data. Data collection methods used in this study are primary data and secondary data. The results showed that Liquidity Risk has a positive and significant effect on Islamic Banking Financial Performance. Net Interest Margin has a positive and significant effect on Islamic Banking Financial Performance, Good Corporate Governance has no and significant effect on Islamic Banking Financial Performance and simultaneously Liquidity Risk, Net Interest Margin and Good Corporate Governance have a positive and significant effect on Islamic Banking Financial Performance.
\end{abstract}

JEL: G30; G10; G24

Keywords: good corporate governance, liquidity risk, net interest margin

i Correspondence: email tonihidayat@umnaw.ac.id, abdulmalik@umnaw.ac.id, disnaanumsrg@umnaw.ac.id, munawaroh@umnaw.ac.id 


\section{Introduction}

Islamic banking is a form of national banking that bases its operations on Islamic sharia. The government's recognition of the specifications of Islamic banking in Indonesia is proven by the enactment of Law Number 21 of 2008 concerning Islamic banking. This Law regulates the operations of Islamic banks so that Islamic banks carry out their operations with sharia principles. This law was enforced based on the phenomenon of the monetary crisis that occurred in 1998, at that time Islamic banking was still able to stand tall among conventional banks that were threatened with liquidation. Islamic banks are able to stand because in their operations based on sharia principles. The biggest challenge faced by the Islamic banking industry in 2017 was liquidity. Tight liquidity can be seen from the decline in third party funds in 2017 to $19.83 \%$ from $22.6 \%$ in the previous year. This is also accompanied by the continued slow growth of market share. Even though it has increased in 2016 by $4.87 \%$ to $5.3 \%$ and $5.44 \%$ in 2017 , the amount is still low if compared to conventional banks. Therefore, the Islamic banking industry in Indonesia is required to improve business performance and maintain banking system stability in the face of banking industry competition. This is because the health of the bank is of vital importance maintaining the stability of the banking system.

From the phenomenon above, it shows that liquidity management is a priority of a financial institution, including banking. Proper liquidity management can support bank health and stability, and reduce the risk of bankruptcy. Liquidity is an indicator measuring the soundness of a bank on its financial performance. To facilitate a bank that is able to overcome liquidity risk can pay all its debts when the customer is billed, and is able to fulfill all credit requests from prospective debtors who are worthy of being financed. Bank liquidity shows the bank's ability to meet short-term obligations. Liquidity from the asset point of view shows the bank's ability to convert assets into cash. Meanwhile, from the liability point of view, liquidity is the ability to meet bank fund needs by increasing the liability portfolio. The function of liquidity in general is used to carry out daily business transactions. In addition, liquidity is used to address urgent funding needs and meet customer demands for financing. Liquidity also provides flexibility to obtain profitable investment opportunities for banks. The financial ratios used to calculate liquidity include the financial debit ratio, the ratio of liquid assets to total assets and the ratio of liquid assets to deposits. Bank profitability determines a bank's ability to raise capital through retained earnings, support future asset growth, absorb loan losses and provide returns to investors. The biggest source of income for Islamic banks is margin income and profit sharing from financing which is calculated by taking income from financing activities minus margin and profit sharing paid on deposits and savings. The second important source of bank income is from investment activities, foreign exchange, commission and transaction fees, and trust operations are also a substantial source of income.

Net Interest Margin is used to measure the level of bank management to generate income from interest by looking at the performance of banks in channeling credit, 
considering that bank operating income is very dependent on the difference in margin. The greater the Net Interest Margin value achieved by the bank, the higher the income on the productive assets managed by the bank, so that the profit at the bank will increase. A bank is said to be healthy if it has a NIM above $6 \%$. The greater this ratio, the more profitable it will be for the bank. This is because a high ratio value indicates an increase in productive assets managed by a bank, which means that the possibility of problems that will arise is also smaller.

Good Corporate Governance is closely related to financial performance in Islamic banking. As for the parties that play a role in financial performance, among others, the Board of Directors, KAP, Managerial Ownership and the Board of Commissioners influence the implementation of Good Corporate Governance. What is meant by the board of directors is someone appointed to lead a limited liability company (PT), the director can be someone who owns the company or a professional person appointed by the business owner, a public accounting firm (KAP) is a business entity that has obtained permission from the company. Minister of Finance is deemed as a forum for public accountants to provide services. Managerial ownership for the number of share ownership owned by the owner, the executive board, and management in a company, the board of commissioners is the company's organ responsible for general oversight and/ or specifically in accordance with the articles of association and provide advice to the board of directors (based on Law No.40 of 2007 on limited liability companies).

Bank performance is a description of the achievements of the bank in its operations, both in terms of financial, marketing, collection and distribution of funds, technology and human resources. Bank financial performance is a description of the bank's financial condition in a certain period, both regarding the aspects of raising funds and channeling funds. One of the tools to measure financial performance is to use profitability indicators. Profitability is the ability of a company to get profit in a certain period. Financial performance is one of the factors that shows the effectiveness and efficiency of an organization in order to achieve its goals. Effectiveness management has the ability to choose the right goals to achieve the goals that have been set.

\section{Literature Review}

\subsection{Liquidity}

Liquidity is a ratio to show or measure the ability of a company to meet its obligations that are due, both obligations to parties outside the company (business entity liquidity) and within the company (company liquidity) (Kasmir, 2016). LDR (Loan to Deposit Ratio) is a banking company financial ratio related to the liquidity aspect

\subsection{Net Interest Margin}

Net Interest Margin is the ratio used to measure the ability of bank management to manage its productive assets to generate net interest income. The greater this ratio, the 
increase in interest income on productive assets managed by the bank, so that the possibility of a bank in a problematic condition is getting smaller (Wijaya, 2009).

\subsection{Good Corporate Governance}

Good Corporate Governance is a process and structure used by company organs (Shareholders / Capital Owners, Commissioners, Board of Trustees and Directors) to increase business success and corporate accountability in order to realize long-term shareholder value while still paying attention to the interests of other stakeholders based on laws and regulations and ethical values (Sutedi, 2011: 1). Based on Bank Indonesia Circular Letter (SEBI) Number 15/15 / DPNP of 2013, the bank carries out routine selfassessment which includes 11 factors, among others, duties and responsibilities of the Board of Commissioners, Implementation of duties and responsibilities of the Board of Directors, Completeness and implementation of Committee duties, Handling of conflicts of interest, Implementation of the compliance function, internal audit function, external audit function, risk management including the internal control system, Provision of funds to related parties party) and the provision of large funds, transparency of bank financial and non-financial conditions, GCG implementation reports and internal reporting, and bank strategic plans.

\subsection{Financial Performance}

Financial performance is an analysis carried out to see the extent to which a company has implemented financial implementation rules properly. Company performance is a description of the financial condition of a company which is analyzed with financial analysis tools, so that it can be seen about the good and bad financial condition of a company that reflects the work performance in a certain period. This is very important so that resources are used optimally in the face of environmental changes (Fahmi, 2012).

\section{Research Methods}

The research used is quantitative research. While the research design used in this study is correlation analysis, which is a type of research carried out with the aim of detecting the extent to which variations in a factor are related (correlated) with one or more other factors based on the correlation coefficient (Sugiyono, 2017). The population in this study is the financial data of 11 Islamic banking companies. With observational data starting from 2018-2020. The technique of determining the number of saturated samples, so that all populations were sampled with a total sample of 33 observation data for 3 years.

Data collection methods used in this study are primary data and secondary data. Primary data is data obtained directly from the source, observed and recorded by researchers. Primary data obtained through data collection techniques with surveys. Secondary data is data that comes from companies that are downloaded through the respective company websites and also obtained through several literature and study theories related to this matter. 


\section{Results and Discussion}

Table 1: The Effect of Liquidity Risk on Islamic Banking Financial Performance Coefficients $^{\mathrm{a}}$

\begin{tabular}{|c|c|c|c|c|c|c|}
\hline \multirow{2}{*}{\multicolumn{2}{|c|}{ Model }} & \multicolumn{2}{|c|}{$\begin{array}{l}\text { Unstandardized } \\
\text { Coefficients }\end{array}$} & \multirow{2}{*}{$\begin{array}{c}\begin{array}{c}\text { Standardized } \\
\text { Coefficients }\end{array} \\
\text { Beta } \\
\end{array}$} & \multirow[t]{2}{*}{$\mathrm{T}$} & \multirow[t]{2}{*}{ Sig } \\
\hline & & B & Std. Error & & & \\
\hline \multirow[t]{4}{*}{1} & (Constant) & -7.174 & 2.664 & & -2.693 & .008 \\
\hline & $\mathrm{CR}$ & .553 & .418 & .104 & 1.325 & .006 \\
\hline & NIM & 15.481 & 1.738 & .697 & 8.907 & .000 \\
\hline & GCG & .598 & .843 & .050 & .709 & .480 \\
\hline
\end{tabular}

In the table above, the coefficients explain that the sig value of 0.004 liquidity is proxied by the current ratio (CR) of 0.006 or less than $5 \%$. This shows that there is a significant influence between the independent variable $\mathrm{CR}$ on the dependent variable ROE, so that making a simple regression model can be continued and interpreted in order to achieve the research objectives. From the regression results obtained the following model: $\mathrm{ROE}=$ - 7,174+0,553 CAR

\subsection{Effect of Liquidity Risk on Financial Performance}

Based on the above results, it can be interpreted that $C R$ has a positive effect on ROE, which means that if there is an increase in the value of $C R, R O E$ will also increase. Based on the value obtained, if the CAR value increases, the ROE value of banks will also increase or vice versa. In general, it can be understood that if a Sharia Bank can increase or decrease its liquidity, this will directly impact the financial performance of the Bank. From another point of view, it can also be understood that an increase in bank liquidity can lead to an increase in income due to the placement of bank liquidity in the form of short-term financing. So that Sharia Banks get benefits in the form of bonuses, fees or profit sharing from this placement due to excess liquidity placement. The results of the study are in accordance with previous research conducted by (L. E. Dewi et al., 2015) which states that LDR has a significant positive effect on ROA. Therefore, the first hypothesis which states that liquidity risk has a positive and significant effect on financial performance is acceptable.

\subsection{The Effect of Net Interest Margin on Financial Performance}

The sig X2 (NIM) value coefficient is 0.000 indicating that the Net Interest Margin variable has a positive effect on Return on Assets. This means that the increase in Net Interest Margin, the higher the Return on Assets will be by 0.002. These results are consistent with research conducted by Ali \& Roosaleh (2017). This is because if Islamic banks can apply and generate net interest margin, it will indicate a good company performance, meaning that any increase in income growth is seen from a good interest margin, then financial performance will grow well which will lead to the progress of the company and will have an impact on the maximum achievement of the company's targets. 


\subsection{Effect of Good Corporate Governance on Performance of Islamic Banking}

The sig X3 (GCG) value coefficient is 0.480 , indicating that the good corporate governance variable has no influence on Return on Assets. It means that the banking body organ system has not been maximized in implementing good corporate governance, this can have an impact on poor management, therefore it is hoped that Islamic banking companies are more responsive in managing on the basis of good corporate governance so that mistakes and frauds do not occur again. With the aim of continuing the target achievement that has been beset can be finally achieved. However, the results of this study are inconsistent with previous research conducted by Haryati \& Kristijadi (2015), Sumarno, Widjaja, \& Subandriah (2016), and (Saifi, 2019) which stated that GCG has a positive and significant effect on financial performance.

\section{Conclusion}

Based on the results of data analysis and research discussion, it can be concluded that Liquidity Risk has a positive and significant effect on Islamic Banking Financial Performance. In general, it can be understood that if a Sharia Bank can increase or decrease its liquidity, this will directly impact the financial performance of the Bank. Net Interest Margin has a positive and significant effect on Islamic Banking Financial Performance. This means that the increase in Net Interest Margin will lead to the higher the Return on Assets Good Corporate Governance has no significant effect on Islamic Banking Financial Performance. This can have an impact on poor management; therefore, it is hoped that the Islamic banking company will be more responsive in managing on the basis of good corporate governance so that mistakes and frauds do not occur again. The company can continue to focus on the target achievement that has been beset can be achieved. Simultaneously Liquidity Risk, Net Interest Margin and Good Corporate Governance have a positive and significant effect on Islamic Banking Financial Performance.

\section{Conflict of Interest Statement}

The authors declare no conflicts of interests.

\section{About the Authors}

Toni Hidayat started a career as an administrative employee at the plantation company of PT.PP London Sumatra, Tbk. While working, he continued his postgraduate education in 2011 and graduated from the North Sumatra University Management Science Study Program in 2013. He is currently working as a lecturer at several private universities and as a permanent lecturer at the Faculty of Economics, Management Study Program at the Muslim Nusantara University Al Washliyah Medan.

Abdul Malik is a lecturer at the Faculty of Economics, Management Study Program at the Muslim Nusantara University Al Washliyah Medan. 
Disna Anum Siregar is a lecturer at the Faculty of Pancasila and Civic Education Program at the Muslim Nusantara University Al Washliyah Medan.

Munawaroh is a lecturer at the Faculty of Economics, Management Study Program at the Muslim Nusantara University Al Washliyah Medan.

\section{References}

Ali, M., dan Roosaleh, L. (2017). Pengaruh Net Interest Margin (NIM), Biaya Operasional terhadap Pendapatan Operasional (BOPO), Loan to Deposit Ratio (LDR) dan NonPerforming Loan (NPL) terhadap Return on Assets (ROA). Jurnal Riset Akuntansi dan Keuangan 5 (2): 1377-92.

Budisantoso, T., dan Nuritomo. (2017). Bank dan Lembaga Keuangan Lain. Jakarta: Salemba Empat.

Dewi, L. E., Herawati, N. T., dan Sulindawati, L. G. E. (2015). Analisis Pengaruh NIM, BOPO, LDR, dan NPL terhadap Profitabilitas (Studi Kasus pada Bank Umum Swasta Nasional yang Terdaftar pada Bursa Efek Indonesia Periode 2009-2013). Jurnal Akuntansi Program S1 3 (1).

Dewi, Y. E. (2017). Pengaruh Risk Profile, Good Corporate Governance, Earning dan Capital terhadap Pertumbuhan Laba. Skripsi.

Dendawijaya, L. (2009). Manajemen Perbankan. Jakarta: Ghalia Indonesia.

Fahmi, Irham (2012). Analisis Laporan Keuangan. Bandung : Alfabeta, 2012.

Hakim, F. (2013). Analisis Pengaruh Rasio NPL, LDR, GCG, NIM, CAR, dan BOPO terhadap Tingkat Kesehatan Bank. Skripsi.

Halim, A. (2015). Manajemen Keuangan Bisnis Konsep dan Aplikasinya. Jakarta: Mitra Wacana Media.

Hardikasari, E. (2011). Pengaruh Penerapan Vorporate Governance terhadap Kinerja Keuangan pada Industri Perbankan yang Terdaftar di BEI Tahun 2006-2008. Skripsi.

Haryati, S., dan Kristijadi, E. (2015). The Effect of GCG Implementation and Risk Profile on Financial Performance at Go-Public National Commercial Banks. Journal of $\begin{array}{lllll}\text { Indonesian Economy } 29 & \text { (3):237-50. }\end{array}$ https://doi.org/10.22146/jieb.v29i3.6471.

Hendro, T., dan Rahardja, C.T. (2014). Bank E Institusi Keuangan Non Bank di Indonesia. Yogyakarta: UPP STIM YKPN.

Kasmir. (2016). Analisis Laporan Keuangan. Jakarta: Raja Grafindo Persada.

Saifi, M. (2019). Pengaruh Corporate Governance dan Struktur Kepemilikan terhadap Kinerja Keuangan Perusahaan. Jurnal Profit 13 (2): 1-11.

SEBI No.9/12/DPNP.2007

SEBI No.15/15/DPNP.2015

Sugiyono (2016). Metode Penelitian Bisnis. Bandung: Alfabeta. 
Toni Hidayat, Abdul Malik, Disna Anum Siregar, Munawaroh

THE EFFECT OF LIQUIDITY, NET INTEREST MARGIN AND GOOD CORPORATE

GOVERNANCE RISK ON SHARIA BANKING FINANCIAL PERFORMANCE

Sumarno, J., Widjaja, S., dan Subandriah. (2016). The Impact of Good Corporate Governance to Manufacturing Firm's Profitability and Firm's Value. Jurnal Ilmu Ekonomi 5 (2): 181- 96. https://doi.org/10.15408/sjie.v5i2.3542.

Creative Commons licensing terms

Authors will retain copyright to their published articles agreeing that a Creative Commons Attribution 4.0 International License (CC BY 4.0) terms will be applied to their work. Under the terms of this license, no permission is required from the author(s) or publisher for members of the community to copy, distribute, transmit or adapt the article content, providing a proper, prominent and unambiguous attribution to the authors in a manner that makes clear that the materials are being reused under permission of a Creative Commons License. Views, opinions and conclusions expressed in this research article are views, opinions and conclusions of the author(s). Open Access Publishing Group and European Journal of Economic and Financial Research shall not be responsible or answerable for any loss, damage or liability caused in relation to/arising out of conflict of interests, copyright violations and inappropriate or inaccurate use of any kind content related or integrated on the research work. All the published works are meeting the Open Access Publishing requirements and can be freely accessed, shared, modified, distributed and used in educational, commercial and non-commercial purposes under a Creative Commons Attribution 4.0 International License (CC BY 4.0). 